Please do not remove this page

RMIT

UNIVERSITY

\title{
The Victorian experience of transitional registration for Chinese Medicine practitioners and its implications for national registration
}

Zhou, Wenyu; Zhang, Anthony Lin; May, Brian; Lin, Vivian; Carlton, Anne-Louise; Xue, Charlie Changli https://researchrepository.rmit.edu.au/esploro/outputs/9921858287501341/filesAndLinks?institution=61RMIT_INST\&index=null

Zhou, W., Zhang, A. L., May, B., Lin, V., Carlton, A.-L., \& Xue, C. C. (2012). The Victorian experience of transitional registration for Chinese Medicine practitioners and its implications for national registration. Australian Health Review, 36(1), 61-67. https://doi.org/10.1071/AH09861

Document Version: Accepted Manuscript

Published Version: https://doi.org/10.1071/AH09861

Repository homepage: https://researchrepository.rmit.edu.au

(C) 2012 AHHA

Downloaded On 2023/04/26 20:03:53 +1000 
Thank you for downloading this document from the RMIT Research Repository.

The RMIT Research Repository is an open access database showcasing the research outputs of RMIT University researchers.

RMIT Research Repository: http://researchbank.rmit.edu.au/

\section{Citation:}

Zhou, W, Zhang, A, May, B, Lin, V, Carlton, A and Xue, C 2012, 'The Victorian experience of transitional registration for Chinese Medicine practitioners and its implications for national registration', Australian Health Review, vol. 36, no. 1, pp. 61-67.

See this record in the RMIT Research Repository at:

http://researchbank.rmit.edu.au/view/rmit:16686

Version: Accepted Manuscript

Copyright Statement: (c) $2012 \mathrm{AHHA}$

Link to Published Version:

http://dx.doi.org/10.1071/AH09861

\section{PLEASE DO NOT REMOVE THIS PAGE}


Manuscript Title: The Victorian Experience of Transitional Registration for Chinese Medicine Practitioners and its implications for National Registration

Authors: List all authors in publication order.

$1^{\text {st }}$ Author Name (including middle initial): Wenyu Zhou

Qualifications: BMed, PhD

Position: Research Fellow

Institution or Affiliation: RMIT University

Address: School of Health Sciences, RMIT University, Victoria, 3083 Australia

Email: Wenyu.zhou@rmit.edu.au

$2^{\text {nd }}$ Author Name (including middle initial): Anthony Lin Zhang

Qualifications: BMed, MPH, PhD

Position: Head of Discipline

Institution or Affiliation: RMIT University

Address: School of Health Sciences, RMIT University, Victoria, 3083 Australia

Email: tony.zhang@rmit.edu.au

$3^{\text {rd }}$ Author Name (including middle initial): Brian H. May

Qualifications: MLit., PhD

Position: Clinical Research Fellow

Institution or Affiliation: RMIT University

Address: School of Health Sciences, RMIT University, Victoria, 3083 Australia

Email: brian.may@rmit.edu.au

$4^{\text {th }}$ Author Name (including middle initial): Vivian K. Lin

Qualifications: BA, MPH, Dr.PH

Position: Professor of Public Health

Institution or Affiliation: La Trobe University

Address: School of Public Health, La Trobe University, Melbourne, VIC Australia

Email: v.lin@latrobe.edu.au

$5^{\text {th }}$ Author Name (including middle initial): Anne-Louise Carlton

Qualifications: BA, BS, MBA

Position: Project Manager, Policy and Legislation

Institution or Affiliation: Department of Human Services, State Government of

Victoria, Australia

Address: Level 12, 120 Spencer Street, Department of Human Services, Melbourne, Australia

Email: Louise.Carlton@dhs.vic.gov.au

$6^{\text {th }}$ Author Name (including middle initial): Charlie Changli Xue (Corresponding Author)

Qualifications: $\mathrm{PhD}$

Position: Head of School and Professor of Chinese Medicine

Address: School of Health Sciences, RMIT University, Victoria, 3083 Australia

Email: charlie.xue@rmit.edu.au 


\section{Acknowledgements}

We thank the support provided by the Chinese Medicine Registration Board of Victoria (CMRBVic), in particular the Registrar Mrs. Debra Gillick. Many staff and students inside and outside RMIT University, particularly, Dr Angela Yang, Dr Nelson Alingcastre and Dr Mary-Jo Bevin, provided significant input to the planning and conduct of the study. 


\begin{abstract}
Background: Statutory registration of Chinese medicine (CM) practitioners was introduced in Victoria in 2000. The application assessment process for those who were granted registration during the transitional period (2002-04) was resource intensive, as little was known about their age, education, practice and language proficiency. This study offers insights that may be useful for the planning of national registration to commence in 2012.

Methods: Data were extracted from registration application forms submitted to the Chinese Medicine Registration Board of Victoria between 2002 and 2004, using pre-defined data collection forms.

Results: In 2006, 639 'grandparented' Victorian CM practitioners had been registered, with a median age of 44 years old (range 23-86). There was a higher number of younger female, Englishspeaking, acupuncturists versus a higher proportion of older male, non-English speaking, Chinese herbalists. There were few CM practitioners in rural areas, particularly herbalists. More than one third of practitioners had obtained qualifications overseas and almost half of these practitioners provided no evidence of past study in professional issues and medical ethics.

Conclusions: Ageing, diversity in qualifications and training, English proficiency, and level of study in professional issues and medical ethics represent major challenges for the implementation of CM national registration in 2012 .
\end{abstract}


1. What is known about the topic?

Statutory registration of Chinese medicine $(\mathrm{CM})$ practitioners was introduced in the state of Victoria in 2000. The process of registering practitioners during the transitional period was resource intensive, because of the diverse background of the workforce. In May 2009, Health Ministers of all States and Territories and the Commonwealth agreed to include the CM profession, from 1 July 2012, in the National Registration and Accreditation Scheme for the health professions.

2. What does this paper add?

This paper, based on data from the registration application forms submitted to the Chinese Medicine Registration Board (CMRB) of Victoria between 2002 and 2004, provides a demographic and geographic profile of the 639 Victorian CM practitioners grandparented under the transitional arrangements of the Chinese Medicine Registration Act 2000. This study offers insights that may be useful for the planning of national registration for the Chinese medicine profession.

3. What are the implications for practitioners?

With the introduction of national registration for the CM profession, this study provides critical data for developing effective strategies to implement the grandparenting process in states and territories other than Victoria, and particularly the need to deal with assessing knowledge in ethics and healthcare system, biomedical sciences and language proficiency as part of assessment process for a substantial number of applicants during the national registration of CM practitioners. 


\section{Introduction}

Complementary and Alternative Medicine (CAM), which includes Chinese medicine (CM), has been increasingly used in Australia. About $2.0 \%$ of the population had visited an acupuncturist in $1993^{1}$ and in 2005, approximately one in five Australians had used CM modalities (9.2\% acupuncture, $7 \%$ herbal medicine and $5.1 \%$ therapeutic massage) over a period of 12 months ${ }^{2}$. Nationally, the number of CM practitioners had increased from around 50 in $1867^{3}$ to at least 4,500 practitioners approximately 15 years ago ${ }^{4}$.

In 1996, a research project was commissioned by the Governments of Victoria, New South Wales and Queensland to review the risks, benefits, practice and usage of CM in Australia which revealed considerable diversity in the educational backgrounds of existing CM practitioners and a range of risks associated with $\mathrm{CM}$ practice ${ }^{4-5}$. Subsequently, statutory regulation of $\mathrm{CM}$ practitioners was recommended to protect public health and safety ${ }^{4-5}$.

In 2000, the CM Registration Act 2000 was passed by the Victorian Parliament. The CM Registration Board of Victoria (CMRB) was established to register acupuncturists (medically qualified acupuncturists were endorsed by the Victorian Medical Board), Chinese herbal medicine (CHM) practitioners and Chinese herbal dispensers, and to investigate complaints about registrants' professional conduct and fitness to practice ${ }^{6}$. More than 1,000 CM practitioners had been registered as of November $2009^{7}$.

The first three years of mandatory registration from January 2002 constituted a transitional period ${ }^{8}$, After 1 January 2005, CM practitioners could only be approved for registration by the CMRB if they had completed a degree level program of study approved by the CMRB or had successfully passed the examinations set by the CMRB ${ }^{8}$. Once approved for registration, practitioners could 
take up registration by paying the required fees, taking out professional indemnity insurance and meeting first aid requirements.

The 1996 study had identified variation in the education and training of the CM workforce in Australia ${ }^{4}$. Consequently, the transitional arrangements (also known as 'grandparenting') developed by the CMRB needed to take into account the historical development of the profession and the diversity in the educational backgrounds of existing practitioners. The CMRB also needed to ensure that existing practitioners could continue to practice while their qualifications, training, experience and competency were assessed to determine their eligibility for general or specific registration under the new Act.

Under the transitional arrangements, applicants who could demonstrate at least five years professional practice in acupuncture, CHM and/or herbal dispensing were considered as 'grandparents'. Such practitioners also required evidence of at least diploma or advanced diploma level of education, needed to be of good character and be professionally competent to meet registration requirements. Recent graduates required at least an advanced diploma level qualification that included specified content in $\mathrm{CM}$, biomedical sciences and clinical training.

Acceptable courses of training (Australian and overseas) were assessed against the Register of Australian Tertiary Education (RATE) requirements for diploma which transitioned into advanced diploma level when the Australian Qualifications Framework (AQF) came into effect. Courses also needed to include a range of key subject areas in $\mathrm{CM}$, medical sciences and practical clinical training. In cases where this level of training evidence was not available, applicants were required to provide evidence of how they undertook their training plus demonstrating ten years professional practice. Applicants with evidence of five but less than ten years practice who were unable to meet the educational requirements could sit CMRB examinations or undertake additional training. 
Recent graduates of CM courses accredited at advanced diploma or above were granted registration during the transitional period.

$\mathrm{CM}$ was the first new CAM profession to be regulated under statutory registration since chiropractic and osteopathy in $1978^{9}$. The diversity in education and training plus the unique cultural issues presented considerable challenges to the new regulatory authority, the CMRB. Mandatory registration in Victoria provided an opportunity to gain an accurate and comprehensive profile of the $\mathrm{CM}$ workforce at the inception of this new regulatory scheme that was likely to be of direct relevance to any future registration of CM practitioners in other states. Consequently, the Discipline of Chinese Medicine at RMIT in collaboration with the CMRB undertook a comprehensive study of all successful registration applications under the transitional arrangements.

Subsequently, in March 2008 the Council of Australian Governments (COAG) decided to establish a single National Registration and Accreditation Scheme for 10 health professions and in May 2009, COAG included the $\mathrm{CM}$ profession in the national scheme ${ }^{10}$. Although Victorian registered CM practitioners are expected to transition to the national scheme which commences on 1 July 2012, the new national board will face similar issues to that of the CMRB with regard to CM practitioners currently practising on the other states.

This workforce study on Victorian CM practitioners registered under grandparenting aims to inform the national implementation of transitional arrangements for CM practitioners in other states and territories, to facilitate the assessment of applicants and to help ensure adequate protection of public health and safety. 


\section{Methodology}

\section{Data Source and Data Collection}

No data had been collected on the Australian CM workforce since $1995^{4}$ which was a voluntary self report survey. With statutory registration, all $\mathrm{CM}$ practitioners who wished to continue to practise legally were required to submit applications. This provided an opportunity to undertake an objective analysis of the total workforce at the inception of regulation.

CMRB permission was sought and ethics approval was obtained from the RMIT Human Research Ethics Committee. Data was drawn from all original registration application documents submitted to the CMRB before the end of 2004 (i.e. during the transitional period). Complete documentation was available on all registrants including the application form, supporting documents such as certified copies of academic records, evidence of membership of professional associations, professional insurance, previous complaints and other character issues. These were stored in individual folders and coded with the application numbers. Rejected, pending or expired registrations as of 30 Dec 2006 were not included in the present study.

All data collection was undertaken by a $\mathrm{PhD}$ research candidate (who was not a registered $\mathrm{CM}$ practitioner) under the direct supervision of the Registrar of the CMRB using a predefined data transfer sheet. No original record or any identifying information was removed from the CMRB office in order to preserve confidentiality and privacy. A random sample (approximately 10\%) of the extracted data was double-checked against the original records by another investigator. No erroneous data were found.

A coding system with fixed values was developed to record specific features of the CM registration application and to ensure consistency in the data collection as well as to facilitate data analyses. The ages of all CM practitioners were calculated as at the end of December 2006 when data collection 
was completed. CM practitioners' educational background information was extracted according to the CMRB's Guidelines for the Approval of Courses of Study in Chinese Medicine as a Qualification for Registration $^{11}$.

\section{Data Analyses}

Data were analysed using the Statistical Package for Social Sciences (SPSS) for Windows, version 16.0. Descriptive statistics were presented for different groups of registered CM practitioners. Chisquare analyses were used to compare the differences between sub-groups of CM practitioners. The relationships between $\mathrm{CM}$ practitioner characteristics were assessed by Spearman Correlation (interval variables). Probability levels less than 0.05 were taken to indicate statistical significance. 


\section{Results}

At the time of data collection (December 2006), 790 Victorian CM practitioners had been approved for registration under the grandparenting arrangements. Almost 20\% of them (151) either did not take up registration or did not renew their registration after their initial registration expired. The demographic data for the remaining 639 registered Victorian CM practitioners is detailed in Table 1.

\section{Divisions of practice}

Of the 639 CM practitioners, nearly two thirds $(n=386,60.4 \%)$ were granted registration in both the acupuncture and CHM divisions. More than one third $(n=225,35.2 \%)$ were granted registration in the division of acupuncture only, with less than 5\% $(n=28)$ in the CHM division only. No-one was registered as a CHM dispenser.

\section{Age and gender}

As shown in Table 1, the mean age of all CM practitioners was 43.6 years (mode=36, median=43.0), ranging from 23 to 86 years. More than half of the Victorian CM practitioners $(60.2 \%)$ were aged between 35 and 54 years and almost half of them (46.9\%), were aged 45 or older. Approximately one in six $(16.1 \%)$ were aged over 55 . Of the 639 practitioners, $54.5 \%$ were male. Females made up $58.3 \%$ of those aged 25 to 34 years, while $61.4 \%$ of those aged $45-54$ years were males. As age increased so did the proportion of males (Spearman correlation $=-0.128, \mathrm{p}=0.001$ ).

With regard to divisions of registration, in all but the highest age bracket (65 years and over), the proportion registered in acupuncture exceeded the proportion registered in CHM. In general, as age increased the difference in the proportion between these two divisions decreased (Spearman correlation $=0.236, \mathrm{p}<0.05)$. However, the greatest difference was in 25-34 years with $95.1 \%$ practising acupuncture but only $40.3 \%$ practising CHM. 


\section{Geographical location of practice}

Nearly nine in ten $(89.8 \%$ ) registrants practised in metropolitan Melbourne, with $35.4 \%$ (225 CM practitioners) in the North \& West Metropolitan areas, 29.2\% (186) in the Eastern Metropolitan areas and 25.2\% (160) in the Southern Metropolitan area. In contrast, the distribution of CM practitioners over the other five Victorian country regions was very thin, with five in Gippsland, nine in each of Grampians and Hume, 17 in Loddon-Mallee and 25 in Barwon South West.

\section{Qualifications}

The majority (96.4\%) of registrants held a diploma level or higher qualification in CM, 62.3\% held a bachelor degree or higher and $14.6 \%$ had completed postgraduate qualifications in CM. In total, $66.4 \%$ had at least one Australian qualification and $43.5 \%$ held a bachelor degree or above from Australia. Overall, $34.9 \%$ had at least one overseas qualification and $61.0 \%$ of them held a bachelor degree or higher. In total, 100 applicants $(15.6 \%)$ had received traditional 'apprenticeship' style training but the majority also had completed formal training. Only $1.1 \%$ was not able to provide assessable evidence of formal training and relied upon evidence of ten or more years of practice and professional competence.

Amongst the older CM practitioners, there were higher proportions of holders of diploma or advanced diploma as their highest qualification. Bachelor qualifications were concentrated in the younger age groups (85.7\% in the 18-24 age group and $81.9 \%$ in the $25-34$ age group). Postgraduate qualifications were more common in those aged 35 years and over (Figure 1).

There was a significant gender difference in qualification level (Chi square $=20.421, p<0.001)$. A larger proportion of males held a postgraduate degree as their highest qualification (16.7\%) when compared with females $(12.0 \%)$. Females were more highly represented in the bachelor degree 
category $(57.4 \%)$, while there was a larger proportion of males with diploma/advanced diploma as their highest qualification $(39.1 \%)$ compared with females $(28.2 \%)$.

The majority of the CM practitioners $(95.1 \%)$ had completed medical sciences studies, such as anatomy, physiology, pathology and microbiology (see Table 2). However, only half of them $(50.3 \%)$ had undertaken studies in professional development, including research methods, ethical and professional issues, small business management, or communication and counselling. Specifically, about two thirds $(66.1 \%)$ of the Australian trained CM practitioners, versus only $10.4 \%$ of those with overseas qualifications only, had completed such studies (Chi square=132.6, $\mathrm{p}<0.001)$.

\section{Clinical practice experience}

The duration of practice was estimated based on the time elapsed between the completion of the first main CM qualification and end of 2006 (Table 1). The average number of years of practice was 13.3 years, ranging from 0 to 52 years. Six practitioners had past medical negligence or other health care claims against them. The length of their CM practice ranged from 8 to 41 years.

\section{First language}

Over half (54.5\%) of the CM practitioners spoke English as their first language and a further 37.9\% spoke Chinese. The proportion of native Chinese speakers was strongly correlated with increasing age $($ Spearman correlation $=0.326, \mathrm{p}<0.05)$, with $81.0 \%$ of those aged 65 years and over having Chinese as their first language compared with $13.9 \%$ in the $25-34$ age group (Figure 2). So, as age increased so did the proportion of native Chinese speakers. A greater proportion of females (59.1\%) spoke English as their first language than males (50.9\%). 
More than half of $\mathrm{CM}$ practitioners whose first language was not English rated their English language skills as 'fluent' in speaking (72.2\%), writing (57.4\%) and reading (65.3\%). Between onequarter and one-third rated their English language skills as 'average' in speaking, writing and reading. Only $13(4.5 \%) \mathrm{CM}$ practitioners considered their spoken English to be at a minimal level.

\section{Discussion}

This study provides a demographic and geographic profile of the 639 Victorian CM practitioners registered under the transitional arrangements of the CM Registration Act 2000. The population consisted of $386 \mathrm{CM}$ practitioners who were registered in the acupuncture and CHM divisions, 225 in acupuncture only and 28 in CHM only. These CM practitioners had to meet the requirements set for registration based on educational background and length of practice. Overall, $23(3.6 \%) \mathrm{CM}$ practitioners could not satisfy the minimum diploma level qualification requirement.

The average age of CM practitioners (43.6 years) appears to have remained fairly constant since $1996^{4}$. Also, a survey of western herbalism and naturopathy found 44 years to be the average practitioner age ${ }^{12}$. Before CM tertiary education was introduced in Australia, many of the enrolees in fee-paying CM courses were in mature age groups. Even in the new degree programs, at least in the case of Victorian tertiary institutions, a substantial proportion of enrolled students have been from the mature age groups.

The gender balance seemed to differ from other healthcare professions in Australia ${ }^{13}$. There were $55 \%$ males and $45 \%$ females in the grandparented CM practitioners. However, in the younger groups of practitioners there is a trend towards female dominance as found in other health care professions in Australia $^{12}$. There were more younger female English speaking acupuncturists and a higher proportion of older male herbalists from a culture and languages other than English (CALD). The explanation is that until recently CM courses in Australia tended to focus on acupuncture only, 
whereas courses in China mostly included both acupuncture and CHM. An increasing number of Australian courses offer CHM education and thus more locally trained English speaking CHM practitioners have entered the workforce recently.

Only $10.2 \%$ of Victorian CM practitioners came from a rural region compared with $89.8 \%$ in metropolitan Melbourne. This imbalance in workforce distribution is not surprising as it is consistent with the distribution pattern for other professions (including general practitioners, dentists, physiotherapists) in rural and remote Australia ${ }^{14-17}$. Unlike medical practitioners ${ }^{18}$, the majority of the rural CM practitioners were locally trained in Australia (85.9\%) and from an English speaking background (89.2\%). Also, even though females tended to dominate the younger age groups, the rural CM practitioners tended to be male and from all age groups.

The diversity of educational backgrounds and English proficiency of older CM practitioners is expected to present issues for the implementation of national registration in CM in 2012. The CM practitioners with qualifications that predate the relatively recent shift to accredited tertiary training comprise another cohort. They typically have diplomas obtained in Australia, the UK and USA as well as in a range of Asian countries. Such qualifications may not satisfy all current educational expectations but may have been the highest level of training available to the CM practitioner at the time. In addition, there was a small cohort of older (45 years upwards) practitioners whose training was difficult to assess e.g. from now-defunct colleges or had lost documentation as a result of war or other events. The approach taken by the CMRB was to set criteria for the various cohorts to enable a combination of formal training, clinical experience, evidence of competence and good character to be taken into account in the assessment process. This was a resource intensive process but it allowed the established CM practitioners to continue practice during the transitional period and it retained expertise within the workforce whilst implementing a minimum standard. It could be expected that similarly complex issues will be faced in the national registration of CM, particularly 
during the transitional period scheduled for 2012 to $2015^{12,19}$. Since the implementation of the CM Registration Act, the CMRB has investigated complaints, some of which have resulted in practitioners' registration being suspended or cancelled ${ }^{20}$. Although there was evidence that key topics relating to medical ethics and safety had not been aspects of past educational programs (especially those from overseas), it could not be determined whether the educational level of grandparented practitioners had any bearing on the nature of these complaints. Data that enables such correlations should be collected at the inception of national registration.

As a retrospective study based on the data available from the registration board, perhaps one limitation of this study is that it fully relied on the information provided by the CM practitioners to the CMRB. It is important to note that practitioners may have provided only the minimum educational qualification in $\mathrm{CM}$ required to qualify them for registration. If practitioners had achieved a higher qualification than that supplied in their application or had undertaken any additional CM professional training, it was not essential for them to provide such evidence. Even so, it is likely that most practitioners provided evidence of their higher CM qualifications to increase the likelihood of their gaining registration. With regard to English proficiency, this data is based on self report and may be subject to bias. On the other hand, this study is not subject to the common limitations of a survey such as response rate, incorrect or subjective responses and, vulnerability to recall bias, since the CMRB data provided accurate documentary information on the whole CM workforce at that time.

\section{Conclusion}

As the first study on all CM practitioners registered under the transitional arrangements, this study provides a comprehensive and accurate profile on the $\mathrm{CM}$ workforce in Victoria at the inception of statutory registration. These findings offer insights into understanding the broad range of operational issues that the CMRB encountered when registration was introduced in 2002 . With the 
introduction of national registration for the CM profession, scheduled to commence in July 2012, data presented may be beneficial for developing effective strategies to administer the grandparenting process in states and territories other than Victoria, and particularly the need to deal with assessing knowledge in ethics and the healthcare system, medical sciences and language proficiency as part of planning for national registration of CM practitioners. 


\section{References}

1. MacLennan AH, Myers SP, Taylor AW. The continuing use of complementary and alternative medicine in South Australia: costs and beliefs in 2004. Med J Aust. 2006;184(1):27-31.

2. Xue CC, Zhang AL, Lin V, Da Costa C, Story DF. Complementary and alternative medicine use in Australia: a national population-based survey. J Altern Complement Med. Jul-Aug 2007;13(6):643-650.

3. Loh M. Victoria as A Catalyst for Western and Chinese Medicine Journal of the Royal Historical Society of Victoria. Journal of the Royal Historical Society of Victoria. 1985;56(3):38-56.

4. Bensoussan A, Myers SP. Towards a safer choice : the practice of traditional Chinese medicine in Australia. Campbelltown, N.S.W. Faculty of Health, University of Western Sydney Macarthur1996.

5. Traditional Chinese medicine: report on options for regulation of practitioners. Melbourne: Victorian Ministerial Advisory Committee; Victorian Government Department of Human Services 1998.

6. Health Professions Registration Act 2005. In: The Parliament of Victoria, ed2005.

7. Ballegaard S, Johannessen A, Karpatschof B, Nyboe J. Addition of acupuncture and selfcare education in the treatment of patients with severe angina pectoris may be cost beneficial: an open, prospective study. J Altern Complement Med. Oct 1999;5(5):405-413.

8. Chinese Medicine Registration Board of Victoria (CMRBVic). Registration of Existing Practitioners pursuant to the "Grandparenting" provisions of section 94 of the Chinese Medicine Registration Act 2000. Act No.18/2000 Victoria, Australia. CMRBVic2002.

9. Victorian Government. Chiropractors and Osteopaths Act 1978. . Melbourne1978.

10. Australian Health Practitioner Regulation Agency. National Registration and Accreditation Scheme2010.

11. Guidelines for the Approval of Courses of Study in Chinese Medicine as a Qualification for Registration. In: Chinese Medicine Registration Board of Victoria, ed. Melbourne2002.

12. Bensoussan A, Myers SP, Wu SM, O'Connor K. Naturopathic and Western herbal medicine practice in Australia-a workforce survey. Complement Ther Med. Mar 2004;12(1):17-27.

13. Armstrong BK, Gillespie JA, Leeder SR, Rubin GL, Russell LM. Challenges in health and health care for Australia. Med J Aust. Nov 5 2007;187(9):485-489.

14. Kamien M, Cameron WI. Solving the shortage of general practitioners in remote and rural Australia: A Sisyphean task? Med J Aust. Dec 4-18 2006;185(11-12):652-653.

15. Adams C, Slack-Smith L, Larson A, O'Grady M. Dental visits in older Western Australians: a comparison of urban, rural and remote residents. Aust $J$ Rural Health. Aug 2004;12(4):143-149.

16. Williams E, D'Amore W, McMeeken J. Physiotherapy in rural and regional Australia. Aust J Rural Health. Dec 2007;15(6):380-386.

17. May J, Jones PD, Cooper RJ, Morrissey M, Kershaw G. GP perceptions of workforce shortage in a rural setting. Rural Remote Health. Jul-Sep 2007;7(3):720.

18. General practice statistics: Table 15, GP headcount by place of basic qualification, 1995-96 to 2006-07. In: Australian Government Department of Health and Ageing, ed2007.

19. Lin V, McCabe PJ, Bensoussan A, et al. The practice and regulatory requirements of naturopathy and western herbal medicine in Australia. Risk Management and Healthcare Policy. 2009;2:21-33.

20. Chinese Medicine Registration Board of Victoria. CMRBVic Fourth Annual Report (20092010). 2010. 
Table 1 Demographic characteristics of all registered practitioners

\begin{tabular}{|c|c|c|c|}
\hline \multirow[t]{2}{*}{ Characteristic } & & \multicolumn{2}{|c|}{$\begin{array}{l}\text { Registered practitioners } \\
\qquad(n=639)\end{array}$} \\
\hline & & $\mathbf{n}$ & $\%$ \\
\hline \multirow{3}{*}{$\begin{array}{l}\text { Division of } \\
\text { registration }\end{array}$} & Acupuncture only & 225 & 35.2 \\
\hline & Chinese herbal medicine only & 28 & 4.4 \\
\hline & Both divisions & 386 & 60.4 \\
\hline \multirow[t]{2}{*}{ Gender } & Male & 348 & 54.5 \\
\hline & Female & 291 & 45.5 \\
\hline \multirow{6}{*}{$\begin{array}{l}\text { Age (years, mean } \\
=43.6)\end{array}$} & $18-24$ & 7 & 1.1 \\
\hline & $25-34$ & 144 & 22.5 \\
\hline & $35-44$ & 188 & 29.4 \\
\hline & $45-54$ & 197 & 30.8 \\
\hline & $55-64$ & 81 & 12.7 \\
\hline & $65+$ & 22 & 3.4 \\
\hline \multirow{6}{*}{$\begin{array}{l}\text { Highest } \\
\text { qualification }\end{array}$} & Postgraduate & 93 & 14.6 \\
\hline & Bachelor degree & 305 & 47.7 \\
\hline & Diploma/advanced diploma & 218 & 34.1 \\
\hline & Short courses & 5 & 0.8 \\
\hline & Apprenticeship & 11 & 1.7 \\
\hline & No assessable qualification & 7 & 1.1 \\
\hline \multirow{5}{*}{$\begin{array}{l}\text { Years elapsed } \\
\text { since graduation } \\
\text { from the main } \\
\text { qualification* }\end{array}$} & $<5$ years & 102 & 16.4 \\
\hline & $5-9$ years & 197 & 31.6 \\
\hline & $10-14$ years & 76 & 12.2 \\
\hline & $15+$ years & 248 & 39.8 \\
\hline & Data not available $^{\#}$ & 16 & - \\
\hline \multirow[t]{4}{*}{ First language } & English & 348 & 54.5 \\
\hline & Chinese & 242 & 37.9 \\
\hline & Others & 47 & 7.4 \\
\hline & Data not available ${ }^{\#}$ & 2 & - \\
\hline \multirow[t]{3}{*}{ Location } & Metropolitan area & 571 & 89.8 \\
\hline & Rural Victorian region & 65 & 10.2 \\
\hline & Data not available $^{\#}$ & 3 & - \\
\hline
\end{tabular}

* The main qualification is the one that is formal and sufficient for registration. In the case of apprenticeship training, years are calculated from the end date.

\# Data not available: i.e. missing data or data not suitable for analysis were excluded. 
Table 2 Training in professional development, basic and biomedical sciences: registered practitioners

\begin{tabular}{|c|c|c|c|c|c|}
\hline \multirow[b]{2}{*}{ Description } & \multirow{2}{*}{$\begin{array}{c}\text { Practitioners } \\
\text { received } \\
\text { training }\end{array}$} & \multicolumn{2}{|c|}{ Qualification $^{2}$} & \multicolumn{2}{|c|}{$\begin{array}{l}\text { Statistical } \\
\text { difference }\end{array}$} \\
\hline & & $\begin{array}{c}\text { At least one } \\
\text { Australian } \\
\text { Qualification }^{3}\end{array}$ & $\begin{array}{c}\text { Overseas } \\
\text { qualificati } \\
\text { on only }\end{array}$ & $\begin{array}{c}\text { Chi } \\
\text { Square }\end{array}$ & $\begin{array}{c}p \\
\text { value }\end{array}$ \\
\hline $\begin{array}{l}\text { Professional } \\
\text { Development including } \\
\text { research methods, } \\
\text { ethical and professional } \\
\text { issues, first aid, small } \\
\text { business management, } \\
\text { and communication } \\
\text { and counselling. }\end{array}$ & $50.3 \%$ & $66.1 \%$ & $10.4 \%$ & 132.6 & 0.000 \\
\hline $\begin{array}{l}\text { Basic and biomedical } \\
\text { sciences including cell } \\
\text { biology, biochemistry } \\
\text { and molecular biology, } \\
\text { anatomy, physiology, } \\
\text { microbiology, } \\
\text { pathology, } \\
\text { pharmacology and } \\
\text { toxicology, phyto- } \\
\text { chemistry and } \\
\text { pharmaceutics, } \\
\text { diagnosis in western } \\
\text { medicine, radiology } \\
\text { and imaging, laboratory } \\
\text { diagnosis, clinical } \\
\text { western medicine and } \\
\text { biomedicine. }\end{array}$ & $95.1 \%$ & $381(96.5 \%)$ & $\begin{array}{c}140 \\
(93.3 \%)\end{array}$ & 2.5 & 0.133 \\
\hline
\end{tabular}

1: \% among practitioners who have provided academic transcripts

2: \% among practitioners who have at least a diploma qualification

3: \% among practitioners with at least one Australian qualification

4: \% among practitioners with overseas qualifications only 
Figure 1: Chinese Medicine Practitioners' Correlations of practitioners' highest qualification and age ranges

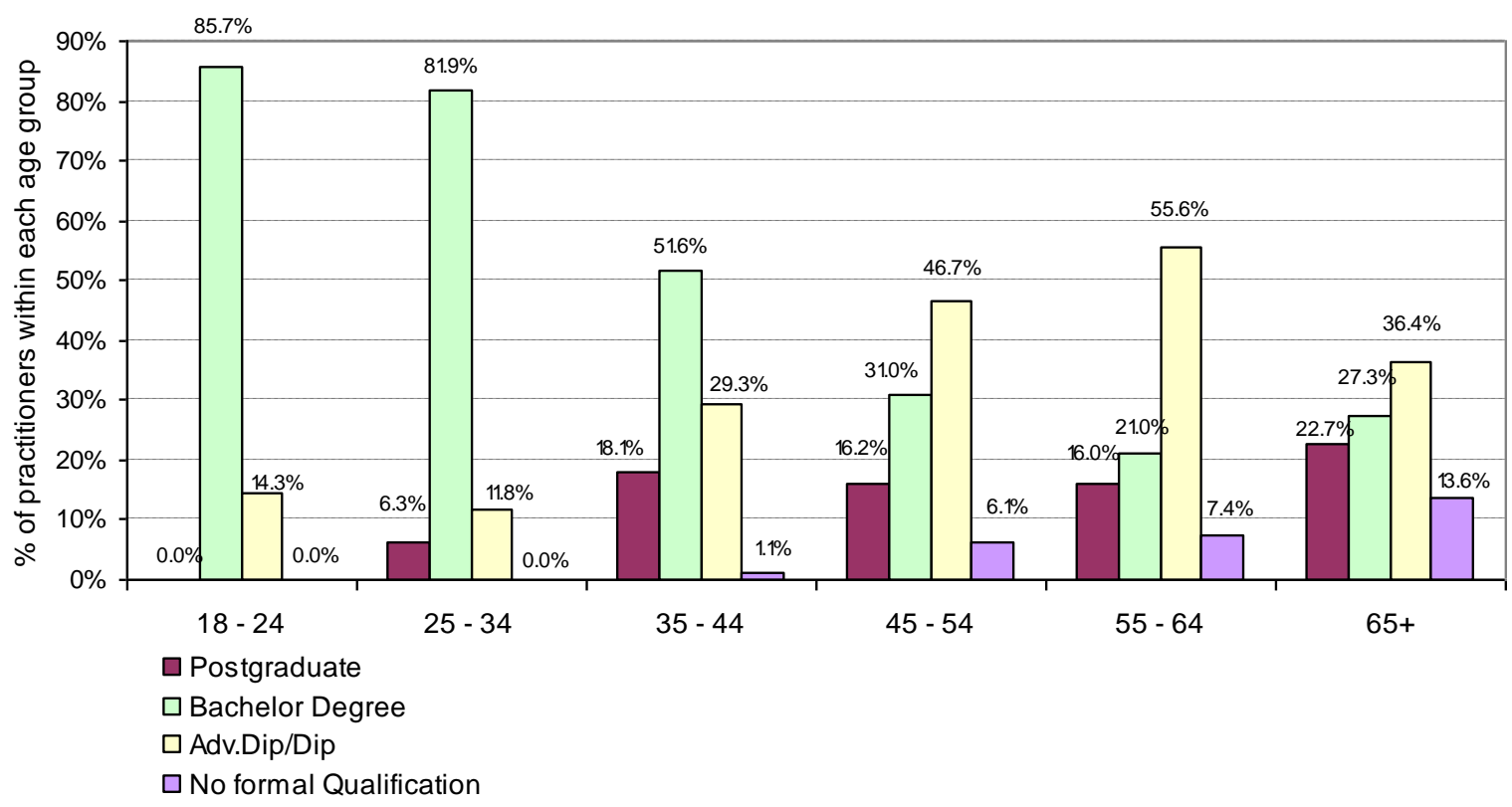


Figure 2: Correlations of practitioners' first language and age ranges

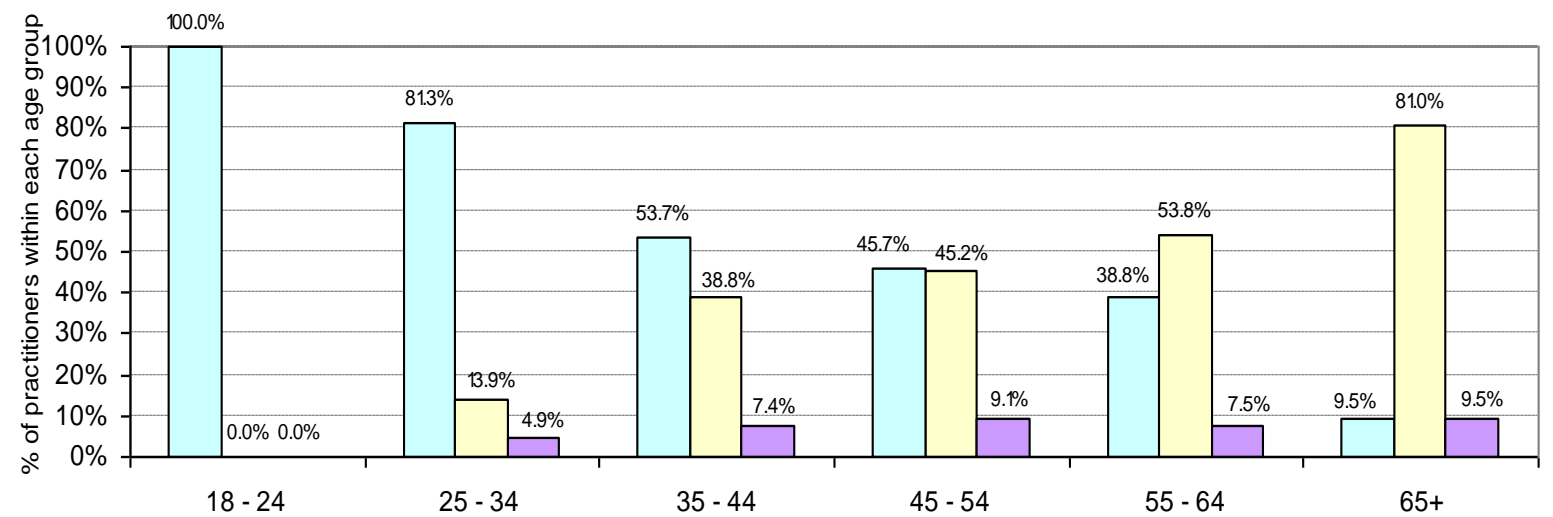

$\square$ English $\square$ Chinese $\square$ Other languages 
(20) 


\section{Australia Health Review \\ Disclosure Statement}

\section{"Always declare a conflict of interest, particularly one that would embarrass you if it came out afterwards" Richard Smith, Editor of BMJ}

Manuscript no: to come

Title: Implementing National Registration in Chinese Medicine in Australia: The Victorian Experience of Transitional Registration for Chinese Medicine Practitioners

Author/s: Wenyu Zhou; Anthony L Zhang; Brian May; Vivian Lin; Anne-Louise Carlton; Charlie CL Xue.

Authors of scientific papers, editorials or letters to the editor are required to indicate financial affiliations with manufacturers of products mentioned in their article(s) or of financial affiliations with manufacturers of competing products.

Each author is required to complete the following statement of financial affiliations. In all cases the questions relate to affiliations with companies who manufacture products mentioned in the article or in companies who manufacture competing products.

\begin{tabular}{|l|l|l|}
\hline Nature of Affiliation & Yes & No \\
\hline $\begin{array}{l}\text { Ownership of stock or stock options or other financial instruments of companies whose } \\
\text { products are mentioned in the article or of companies who manufacture competing } \\
\text { products (does not include mutual fund ownership) }\end{array}$ & No \\
\hline $\begin{array}{l}\text { Ongoing paid consultancy with company or a competitor (actual or within the last 2 } \\
\text { years) }\end{array}$ & & No \\
\hline Employment with company or competitor (actual or within the last 2 years) & & No \\
\hline $\begin{array}{l}\text { Honorarium or other compensation for writing the article or for participating in the } \\
\text { development of the article }\end{array}$ & No \\
\hline $\begin{array}{l}\text { Honorarium or other compensation for conducting research related to material contained } \\
\text { in the article }\end{array}$ & & No \\
\hline Speaker fees and/or educational grants & & No \\
\hline Travel assistance to attend meetings & No \\
\hline
\end{tabular}

If the answer to any of the above questions is "yes", please provide details.

Please specify any source/s of funding and its/their role in study design, data collection, analysis and interpretation, and writing or publication of this paper.

Are there any other (non-financial) competing interests that you wish to declare?

N/A

Date 04 December $2009 \quad$ Name: Wenyu Zhou

(NB: We do not require a signature for this statement, which can be emailed) 


\section{Australia Health Review \\ Disclosure Statement}

\section{"Always declare a conflict of interest, particularly one that would embarrass you if it came out afterwards" Richard Smith, Editor of BMJ}

Manuscript no: to come

Title: Implementing National Registration in Chinese Medicine in Australia: The Victorian Experience of Transitional Registration for Chinese Medicine Practitioners

Author/s: Wenyu Zhou; Anthony L Zhang; Brian May; Vivian Lin; Anne-Louise Carlton; Charlie CL Xue.

Authors of scientific papers, editorials or letters to the editor are required to indicate financial affiliations with manufacturers of products mentioned in their article(s) or of financial affiliations with manufacturers of competing products.

Each author is required to complete the following statement of financial affiliations. In all cases the questions relate to affiliations with companies who manufacture products mentioned in the article or in companies who manufacture competing products.

\begin{tabular}{|l|l|l|}
\hline Nature of Affiliation & Yes & No \\
\hline $\begin{array}{l}\text { Ownership of stock or stock options or other financial instruments of companies whose } \\
\text { products are mentioned in the article or of companies who manufacture competing } \\
\text { products (does not include mutual fund ownership) }\end{array}$ & No \\
\hline $\begin{array}{l}\text { Ongoing paid consultancy with company or a competitor (actual or within the last 2 } \\
\text { years) }\end{array}$ & & No \\
\hline Employment with company or competitor (actual or within the last 2 years) & & No \\
\hline $\begin{array}{l}\text { Honorarium or other compensation for writing the article or for participating in the } \\
\text { development of the article }\end{array}$ & No \\
\hline $\begin{array}{l}\text { Honorarium or other compensation for conducting research related to material contained } \\
\text { in the article }\end{array}$ & & No \\
\hline Speaker fees and/or educational grants & & No \\
\hline Travel assistance to attend meetings & No \\
\hline
\end{tabular}

If the answer to any of the above questions is "yes", please provide details.

Please specify any source/s of funding and its/their role in study design, data collection, analysis and interpretation, and writing or publication of this paper.

Are there any other (non-financial) competing interests that you wish to declare?

N/A

Date 04 December $2009 \quad$ Name: Anthony L Zhang

(NB: We do not require a signature for this statement, which can be emailed) 


\section{Australia Health Review \\ Disclosure Statement}

\section{"Always declare a conflict of interest, particularly one that would embarrass you if it came out afterwards" Richard Smith, Editor of BMJ}

Manuscript no: to come

Title: Implementing National Registration in Chinese Medicine in Australia: The Victorian Experience of Transitional Registration for Chinese Medicine Practitioners

Author/s: Wenyu Zhou; Anthony L Zhang; Brian May; Vivian Lin; Anne-Louise Carlton; Charlie CL Xue.

Authors of scientific papers, editorials or letters to the editor are required to indicate financial affiliations with manufacturers of products mentioned in their article(s) or of financial affiliations with manufacturers of competing products.

Each author is required to complete the following statement of financial affiliations. In all cases the questions relate to affiliations with companies who manufacture products mentioned in the article or in companies who manufacture competing products.

\begin{tabular}{|l|l|l|}
\hline Nature of Affiliation & Yes & No \\
\hline $\begin{array}{l}\text { Ownership of stock or stock options or other financial instruments of companies whose } \\
\text { products are mentioned in the article or of companies who manufacture competing } \\
\text { products (does not include mutual fund ownership) }\end{array}$ & No \\
\hline $\begin{array}{l}\text { Ongoing paid consultancy with company or a competitor (actual or within the last 2 } \\
\text { years) }\end{array}$ & & No \\
\hline Employment with company or competitor (actual or within the last 2 years) & & No \\
\hline $\begin{array}{l}\text { Honorarium or other compensation for writing the article or for participating in the } \\
\text { development of the article }\end{array}$ & No \\
\hline $\begin{array}{l}\text { Honorarium or other compensation for conducting research related to material contained } \\
\text { in the article }\end{array}$ & & No \\
\hline Speaker fees and/or educational grants & & No \\
\hline Travel assistance to attend meetings & No \\
\hline
\end{tabular}

If the answer to any of the above questions is "yes", please provide details.

Please specify any source/s of funding and its/their role in study design, data collection, analysis and interpretation, and writing or publication of this paper.

Are there any other (non-financial) competing interests that you wish to declare?

N/A

Date $\quad$ December $2009 \quad$ Name: Brian May

(NB: We do not require a signature for this statement, which can be emailed) 


\section{Australia Health Review \\ Disclosure Statement}

\section{"Always declare a conflict of interest, particularly one that would embarrass you if it came out afterwards" Richard Smith, Editor of BMJ}

Manuscript no: to come

Title: Implementing National Registration in Chinese Medicine in Australia: The Victorian Experience of Transitional Registration for Chinese Medicine Practitioners

Author/s: Wenyu Zhou; Anthony L Zhang; Brian May; Vivian Lin; Anne-Louise Carlton; Charlie CL Xue.

Authors of scientific papers, editorials or letters to the editor are required to indicate financial affiliations with manufacturers of products mentioned in their article(s) or of financial affiliations with manufacturers of competing products.

Each author is required to complete the following statement of financial affiliations. In all cases the questions relate to affiliations with companies who manufacture products mentioned in the article or in companies who manufacture competing products.

\begin{tabular}{|l|l|l|}
\hline Nature of Affiliation & Yes & No \\
\hline $\begin{array}{l}\text { Ownership of stock or stock options or other financial instruments of companies whose } \\
\text { products are mentioned in the article or of companies who manufacture competing } \\
\text { products (does not include mutual fund ownership) }\end{array}$ & No \\
\hline $\begin{array}{l}\text { Ongoing paid consultancy with company or a competitor (actual or within the last 2 } \\
\text { years) }\end{array}$ & & No \\
\hline Employment with company or competitor (actual or within the last 2 years) & & No \\
\hline $\begin{array}{l}\text { Honorarium or other compensation for writing the article or for participating in the } \\
\text { development of the article }\end{array}$ & No \\
\hline $\begin{array}{l}\text { Honorarium or other compensation for conducting research related to material contained } \\
\text { in the article }\end{array}$ & & No \\
\hline Speaker fees and/or educational grants & & No \\
\hline Travel assistance to attend meetings & No \\
\hline
\end{tabular}

If the answer to any of the above questions is "yes", please provide details.

Please specify any source/s of funding and its/their role in study design, data collection, analysis and interpretation, and writing or publication of this paper.

Are there any other (non-financial) competing interests that you wish to declare?

N/A

Date $\quad$ December $2009 \quad$ Name: Prof Vivian Lin

(NB: We do not require a signature for this statement, which can be emailed) 


\section{Australia Health Review \\ Disclosure Statement}

\section{"Always declare a conflict of interest, particularly one that would embarrass you if it came out afterwards" Richard Smith, Editor of BMJ}

Manuscript no: to come

Title: Implementing National Registration in Chinese Medicine in Australia: The Victorian Experience of Transitional Registration for Chinese Medicine Practitioners

Author/s: Wenyu Zhou; Anthony L Zhang; Brian May; Vivian Lin; Anne-Louise Carlton; Charlie CL Xue.

Authors of scientific papers, editorials or letters to the editor are required to indicate financial affiliations with manufacturers of products mentioned in their article(s) or of financial affiliations with manufacturers of competing products.

Each author is required to complete the following statement of financial affiliations. In all cases the questions relate to affiliations with companies who manufacture products mentioned in the article or in companies who manufacture competing products.

\begin{tabular}{|l|l|l|}
\hline Nature of Affiliation & Yes & No \\
\hline $\begin{array}{l}\text { Ownership of stock or stock options or other financial instruments of companies whose } \\
\text { products are mentioned in the article or of companies who manufacture competing } \\
\text { products (does not include mutual fund ownership) }\end{array}$ & No \\
\hline $\begin{array}{l}\text { Ongoing paid consultancy with company or a competitor (actual or within the last 2 } \\
\text { years) }\end{array}$ & & No \\
\hline Employment with company or competitor (actual or within the last 2 years) & & No \\
\hline $\begin{array}{l}\text { Honorarium or other compensation for writing the article or for participating in the } \\
\text { development of the article }\end{array}$ & No \\
\hline $\begin{array}{l}\text { Honorarium or other compensation for conducting research related to material contained } \\
\text { in the article }\end{array}$ & & No \\
\hline Speaker fees and/or educational grants & & No \\
\hline Travel assistance to attend meetings & No \\
\hline
\end{tabular}

If the answer to any of the above questions is "yes", please provide details.

Please specify any source/s of funding and its/their role in study design, data collection, analysis and interpretation, and writing or publication of this paper.

Are there any other (non-financial) competing interests that you wish to declare?

N/A

Date 04 December $2009 \quad$ Name: Anne-Louise Carlton

(NB: We do not require a signature for this statement, which can be emailed) 


\section{Australia Health Review \\ Disclosure Statement}

\section{"Always declare a conflict of interest, particularly one that would embarrass you if it came out afterwards" Richard Smith, Editor of BMJ}

Manuscript no: to come

Title: Implementing National Registration in Chinese Medicine in Australia: The Victorian Experience of Transitional Registration for Chinese Medicine Practitioners

Author/s: Wenyu Zhou; Anthony L Zhang; Brian May; Vivian Lin; Anne-Louise Carlton; Charlie CL Xue.

Authors of scientific papers, editorials or letters to the editor are required to indicate financial affiliations with manufacturers of products mentioned in their article(s) or of financial affiliations with manufacturers of competing products.

Each author is required to complete the following statement of financial affiliations. In all cases the questions relate to affiliations with companies who manufacture products mentioned in the article or in companies who manufacture competing products.

\begin{tabular}{|l|l|l|}
\hline Nature of Affiliation & Yes & No \\
\hline $\begin{array}{l}\text { Ownership of stock or stock options or other financial instruments of companies whose } \\
\text { products are mentioned in the article or of companies who manufacture competing } \\
\text { products (does not include mutual fund ownership) }\end{array}$ & No \\
\hline $\begin{array}{l}\text { Ongoing paid consultancy with company or a competitor (actual or within the last 2 } \\
\text { years) }\end{array}$ & & No \\
\hline Employment with company or competitor (actual or within the last 2 years) & & No \\
\hline $\begin{array}{l}\text { Honorarium or other compensation for writing the article or for participating in the } \\
\text { development of the article }\end{array}$ & No \\
\hline $\begin{array}{l}\text { Honorarium or other compensation for conducting research related to material contained } \\
\text { in the article }\end{array}$ & & No \\
\hline Speaker fees and/or educational grants & & No \\
\hline Travel assistance to attend meetings & No \\
\hline
\end{tabular}

If the answer to any of the above questions is "yes", please provide details.

Please specify any source/s of funding and its/their role in study design, data collection, analysis and interpretation, and writing or publication of this paper.

Are there any other (non-financial) competing interests that you wish to declare?

N/A

Date 04 December $2009 \quad$ Name: Prof Charlie Changli Xue

(NB: We do not require a signature for this statement, which can be emailed) 